\title{
Lysozyme Measurement
}

National Cancer Institute

\section{Source}

National Cancer Institute. Lysozyme Measurement. NCI Thesaurus. Code C120640.

The determination of the lysozyme present in a sample. 